DOI: https://doi.org/10.31392/NZ-npu-142.2019.28

УДК 378.147:811.111

Kobylianska Iryna

\title{
THE POTENTIAL FEASIBILITY OF STUDENTS DEVELOPMENT SPEAKING IN THE EFL CLASSROOM AT HIGH LEVELS
}

This article describes conditions and the potential feasibility of learning speaking in the EF $L$ classroom; what successful speaking entails as at the surface level as well as at a more deeplystuctured level of study. The main psycholinguistic tasks were suggested by Levelt, namely: conceptualization, formulation, articulation, self-monitoring and automation. The challenges that teachers face when teaching speaking - especially at high levels and the difficulties students have to cope with and overcome when attempting to speak for eign language have covered in the article. If the atmosphere in the group is hostile and the student concerned is afraid of being ridiculed, speaking becomes imposible. Many problems may appear and language users have to adjust our conversation. Being knowledgeable with certain rules and principles in the abstract is not enough. In order to send an oral message, speakers should be skilful at it.

Teachers are crucial in the view of learning to speak that students may have. Teachers can and should do a great deal to pave the way to more EFL speaking in class. The more oral practice students encounter in class, using the proper techniques, creating a supportive atmosphere in class, the better language users they'll gradually become.

Keywords: teaching of speaking, for eign language, students, learning to speak, challenges.

It is important to be fully aware of the true nature and conditions of speech in order to understand neatly what successful speaking comprehends and requires. At the surface level, one may claim the speaking effectively equally implies being able to listen and to understand, as these skills very often co-occur. Speaking, thus, is essentially reciprocal because any interlocutor may contribute at any time to the development of the discourse, and to respond quickly to anyone else's hint.

The aim of the article is to describe the main queries concerning the teaching of speaking, conditions and particular challenges that dealing with speaking at advanced levels pose.

At a more deeply-structured level of study, speaking should regarded as a general macro-skill which is made up of several processes. Levelt suggested that speech production implies four major psycholinguistic tasks, namely: conceptualisation, formulation, articulation and self-monitoring [8]. Conceptualisation has to do with planning the content of the message to be transmitted. Formulation is the stage in which the speaker finds the actual words and phrases (necessary to convey the intended meaning), sequences them and inserts the adequate grammatical links. Articulation is the process concerned with the organs of producing speech. Finally, self-monitoring is the phase in which one notices the mistakes and self-repairs[1].

Automation is required for effective spoken language, so any potential user of any language should develop it. However any speaker's attention capacity is limited. If attention is shifted from one of the processes to another, how can automation deploy? Skehan has shown that the speakers' fluency, accuracy and complexity of 
speech all demand capacity and that there is likely to be a sort of trade-off among these constituents of the skill [12]. Increasing attention to one would almost inevitably limit one's capacity for the others. As Bygate puts it: "Getting learners to focus on accuracy is likely to encourage a less exploratory or fluent use of the language [4]. Pushing them to develop fluency, on the other hand, might encourage greater use of formulaic chunks of language, discouraging attention to accuracy and reducing speakers' capacity for processing complex language. Leading them to experiment with new expressions or new combinations of words and phrases might jeopardise their accuracy or fluency" [3].

To the above stated, we should add that because in most cases speech is produced literally against the clock and it is unrehearsed, a successful speaker must also develop the ability to make quick decisions (such as, for example, on the exact wording) on the spot as s-/he does not usually enjoy much time for re-drafting. Actually, time pressure is one of the major constraints of naturally occurring speech. Because speakers have little time to organise and execute their message, they often explore phrasing as they speak. The kind of behaviour that speakers tend to show while using the language gives rise to four ordinary characteristics of spoken language that Bygate has explored and explained [4]. Then, for him, speech is typically characterised by: (1) improvisation and the use of less complex syntax, (2) incomplete sentences, broken clauses and abbreviations, (3) use of fixed conventional language or "formulaic expressions", and (4) devices to gain time to elaborate one's message and give shape to one's thoughts, such as "fillers", pauses or hesitations. Bygate has established a differentiation between "facilitation devices" and "compensation devices"[4]. Facilitating features include simplification, ellipsis, formulaic expressions ad fillers. "Compensation features" include self-correction, false starts, repetition and rephrasing. These features: "all help reduce memory load, just as they help to lighten the planning load".

Because when we speak: "we do not merely know how to assemble sentences in the abstract (but) we have to produce them and adapt them to the circumstances. This means making decisions rapidly, implementing them smoothly, and adjusting our conversation as unexpected problems appear in our path", a competent speaker is the one who has both knowledge and skill as we have already anticipated above[5]. Concerning knowledge, speakers must know the rules for accuracy. We know how to combine words and compose sentences. We can decide whether sentences are right or wrong. We can understand and memorize things. This knowledge, coming from different sources, is essential for performing a language in its oral mode. As regards this skill, it is interesting to note the extent to which speaking is an activity that implies quick decisions. Many problems may appear and language users have to adjust our conversation. We can rehearse, practise and imitate how to do this. Being knowledgeable with certain rules and principles in the abstract is not enough. In order to send an oral message, speakers should be skilful at it [7].

Bearing in mind this dichotomy ("knowledge" vs. "skill") is preeminent for the FL teacher given that the effective deployment of each one demands a different proper pedagogy. If we are to really create the conditions for speaking to emerge in class, we will have to help our students by (1) providing them with the required knowledge, plus (2) offering manifold opportunities in class in which they could rehearse and 
imitate certain features of the skill so as to develop it successfully.

The fact that especially at high levels, speaking is somehow elusive and transient - we have stated before that it is spontaneous and, as such, almost impossible to anticipate - makes it very difficult to reduce it automatically to preestablished patterns. Learners could more or less straightforwardly be instructed on knowledge about the target language, but what is the ideal practice to offer to them in each case so that they develop the required skill to speak naturally? How should speaking activities be sequenced? What are the criteria to apply in order to determine the degree of difficulty that each activity poses? These, and other questions alike, lead to a certain kind of uncertainty on the teacher's side which means an important drawback for its teaching because teachers could easily wonder whether it is worthwhile to invest class time in such a comprehensive and complex task, or even hesitate whether there is something they can realistically do to teach speaking successfully. The challenge that teachers face when teaching speaking especially at high levels, as we have already said - is that the lesson becomes less predictable than the comforting series of steps that more controlled activities at lower levels may bring about[9].

There are specific difficulties students have to cope with and overcome when attempting to speak through a language which is not their LI:

1. We should underline that FL speaking is far more difficult for students than speaking in their LI. This is mainly due to the gaps and even obstacles that might arise: "Our students can communicate their ideas and emotions using their LI with fluency, maturity and certain depth of thinking, but in English they have serious limitations and lack of language".

2. Without positive feedback, learners will hardly make headway in speaking, because: "students often underestimate their oral ability". Learning speaking should become an altogether positive experience and the teacher's support and guidance becomes essential.

3. Another remarkable constraint is the inhibition that public speaking often causes. This could make students reticent to speak: "learners are often inhibited about trying to say things in a foreign language in the classroom: worried about making mistakes, fearful of criticism or losing face, or simply shy of the attention that their speech attracts". It becomes immediately apparent the obvious unrest and unease that many students show when they are asked to communicate in class through the L2. Then, it is not surprising that they exhibit overt reluctance to take part in oral activities, silence being the principal characteristic of many (supposedly) oral lessons.

4. The atmosphere of the class may not be welcoming but one that invites not to utter a single word. We can't overlook that creating a certain mood in the class environment is absolutely important. In this sense, a friendly, lively and relaxed atmosphere will bring about a pleasant sort of group feeling that will make things easier for students. After all: "Speaking is not something that everyone does with ease. It becomes impossible, even for the most extrovert person, if the atmosphere in the group is hostile and the learner concerned is afraid of being ridiculed or mocked". Students must feel secure so as to decide that they want to speak in class.

5. Sometimes the students' reticence to speak is based simply in their lack of interest in what is happening in class. If the students perceive class activities as 
irrelevant they lose their motivation. This has a terribly negative impact on their process of learning as learners might stop getting dynamically involved in class.

Two essential aspects of students' active participation in class are their selfconfidence and their motivation. Both are intimately related: if teachers are to instil confidence in students, motivation is the most important ingredient that must certainly be used. If students are interested in what takes place in class, they will build and deploy a feeling of "I can cope", will show eagerness to participate and, by accumulating practice, they will develop self-confidence[14].

It is essential to search motivating activities. Motivation is directly linked to interest and positive attitude, eagerness to assume responsibility and readiness to make the effort that language learning requires. Teachers can do a lot in this regard to facilitate students' production in the target language by choosing engaging and motivating activities, which should have real interest for the students: "Students learn best when they're interested in what they're doing. That means that they won't speak E nglish if it feels irrelevant [or if] they don't want to".

6 . We also have to take into account the extent to which practising speaking is time-consuming. It takes a long time to give shape to one's thoughts and then choose the actual wording in a non-native language. Learners do not generally have enough time to elaborate their utterances carefully under the restrictions of the limited time span given in class for every activity and this at times leads to mistakes: "when we speak, we have to build up the message and articulate quickly, so we are more spontaneous and consequently we frequently make mistakes -which we sometimes notice later. Time constraint is a factor of remarkable importance and students usually find themselves under strong pressure.

7. Because of the shortage of time to articulate messages, teachers should help learners by making them fully aware of the importance of resorting to whatever language they already know. The aim is to be understood. That is why the activities provided should foster the deplopment of the most adequate strategies to fill potential gaps that might stop the communication process. With the passage of time and accumulated experience, learners will become more competent, thus progressively needing to rely less and less on strategies - though even proficient speakers occasionally may find them useful and make use of them.

When facing EFL teaching, speaking generally poses particular difficulties to the teaching practitioner in question, too. The most outstanding ones are the following:

1. Teachers find it difficult to assess whether we have been successful at teaching speaking. Even reflecting upon our own experience after having dealt with it may at times provide us with mixed feelings about our performance. How can teachers really notice progress in our students' ability to speak after them having taken a course?

2. All teachers want to make the most of any instance of class. Effectiveness is regarded as a must. When teaching speaking, teachers are fully aware of the challenge of determining precisely what "speaking perfectly" involves. What do we mean by such a concept? Are we thinking of "speaking fluently"? Is it a question of "speaking accurately"? Do we aim at helping our students to "speak with a wealth of vocabulary"? Maybe "with an ample range of idiomatic expressions"? Do we have "speaking in a culturally appropriate way" in mind? 
3. Classes are heterogeneous, and students bring a myriad of different characteristics with them (age, cultural background, personality, gender, etc.). Some of these features may bias certain learners' attitude and performance in class more strongly than others and hence the students' willingness to take part in oral activities will vary considerably. It is important to take into account that students' lack of participation does not automatically mean that they lack the ability to do so. It may just be that some circumstances (either theirs or in the environment) may be inhibiting or blocking them somehow. Then, how can teachers cope with these issues? How should teachers address the likely students' uneven participation?

4. As stated before, speaking activities tend to be time-consuming, and teachers often complain that class time is too reduced to be able to cover everything that students would need for successful language achievement. Planning carefully what to do and how to perform things is essential. Both the provision of quality input plus that of opportunities for oral interaction will have to be balanced in a conscientious way. Teachers want to maximise students' talking time (STT), as it is of paramount importance in learning speaking. How can teachers know for sure that students are making the most of their STT?

5. Assessing speaking is challenging and dealing smoothly with students' errors is not easy. How can teachers be sure that they are properly qualified to decide what should be corrected (or ignored), when and how to do it? How can teachers find out ways to provide learners with valuable feedback so that it may have a learning impact on students? [10]

The above compiled list of difficulties should not discourage teachers or make us believe that the development of this skill under instruction is unfeasible. As long as teachers resort to proper techniques, create a supportive atmosphere in class, and include speaking systematically in their syllabi, the teaching of this skill may be similarly enriching and successful to that of any other.

Bearing all the issues we have been discussing so far in mind, we can conclude that the teacher's role in the oral class is absolutely important. As with every other aspect of our teaching, successful and effective performance aimed at making students deploy EFL speaking will depend more on our own belief and attitude than on the training we have previously had. If we perceive the teaching of speaking as insurmountable task, then we'll do almost nothing to help learners develop this skill. Deploying EFL speaking, though demanding, is neither unfeasible nor unattainable. It does require guidance and support on the part of the teacher, and accumulated time and systematic practice on the students' side. That is why in spite of its complexity "teachers should not cease in their attempts to bring about speaking in students: it is always in the hands of the teacher to decide whether to include speaking as an ordinary constituent of classes or not". Only when oral practice plays a role regularly in our lessons will learners steadily become competent at the productive skill of speaking. Teachers can contribute significantly to turn mere students of English, with a vast knowledge of grammar and structures, into ordinary users of English as a true means of communication.

\section{R ef erences:}

[1] A rnold, J. (2002). "Speak Easy", Oral Skills: Resources and Proposals for the classrooms, 51-64.

[2] Brown, C. J. (1983). Teaching the Spoken L anguage. Cambridge: C.U.P. 
[3] B rumfit, C. J. (1984). Communicative M ethodology in L anguage Teaching. Cambridge: C.U.P.

[4] Bygate, M. (1987). Speaking. Oxford: O.U.P.

[5] Folse, K. S. (2006). The A rt of Teaching Speaking. M ichigan: The U niversity of M ichigan Press.

[6] Harmer, J. (1983). The Practice of English Language Teaching. London: L ongman.

[7] Hedge, T. (2000). Teaching and L earning in the L anguage Classroom. Oxford: O.U.P.

[8] Levelt, W.J.M. (1989). Speaking: from Intention to Articulation. Cambridge, M A.:M .I.T.

[9] M ontijano, M . P. (2003). "Helping EFL Students Deploy Speaking Under Instruction: a Sensible A im or a Mere U topia?", CETA M agazine, 5, 36-41.

[10] M ontijano, M. P. (2003). "Getting the right balance among variables when implementing EFL speaking activities", Granada: Ediciones A dhara, 91-100.

[11] Rivers, W. and Temperley, R. S. (1978). "A Practical Guide to the Teaching of English", New Y ork: O.U.P.

[12] Skehan, P. A (1998). Cognitive A pproach to L anguage Learning. Oxford: O.U.P.

[13] Tejada, G. and N ieto, J. M . (1996). "Oral communication". A Handbook for TEFL . Alcoy: Marfil, 239-258.

[14] Tomlinson, B. (2001). "M aterials development": The Cambridge Guide to Teaching English to Speakers of Other L anguages. Cambridge: C.U.P.

КоБИлянСьКА І. В. Потенційна можливість розвитку мовлення студентів на уроках іноземної англійської мови на вищих рівнях.

Стаття описує умови та потенційну можливість навчання говоріння на уроках іноземної англійської мови, що тягне за собою успішне мовлення як на поверхневому, так $і$ на глибокому рівні навчання. Основні психолінгвістичні завдання були запропоновані Левелтом, а саме: конщептуалізачія, формулювання, артикуляиія, самоконтроль та автоматизація. У статті висвітлюються проблеми, з якими стикаються викладачі при викладанні усного мовлення особливо на високих рівнях, - та труднощі, з якими студенти повинні впоратися і долати, пробуючи говорити іноземною мовою. Якщо атмосфера в групі ворожа для студентів, які стурбовані, щуо над ними насміхаються, мовлення стає неможливим. Багато проблем може з'явитися під час розмови, i користувачі мови повинні пристосувати розмову до умов. Знання певних правил та принципів в абстрактному вигляді недостатньо. Для того щэоб відправити усне повідомлення, доповідачі повинні бути в цььому вправними.

Викладачі мають вирімальне значення у погляді навчання говоріння, що студенти можуть мати. Викладачі можуть і повинні зробити багато для того, щоб прокласти шлях до більшої кількості говоріння іноземною англійською мовою у класі. Чим більшою буде усна практика, з якою стикаються студенти у класі, використовуючи відповідні методики, створюючи сприятливу атмосферу, тим кращими споживачами мови вони поступово стануть.

Ключові слова: викладання мови, іноземна мова, студенти, навчання говоріння, проблеми.

КоБЫЛЯнСКАЯ И.В. Потенциальная возможность развития речи студентов на уроках иностранного английского языка на высших уровнях.

Статья описывает условия и потенциальную возможность обучения говорения на уроках иностранного английского язика, что влечет за собой успешная речь как на поверхностном, так и на глубоком уровне обучения. Основные психолингвистические задачи были предложены Левелтом, а именно: конщептуализация, формулировка, артикуляция, самоконтроль и автоматизация. В статье освещаются проблемы, с которыми сталкиваются преподаватели при преподавании устной речи - особенно на высоких уровнях, - и трудности, с которыми студенты долюны справиться и преодолеть, пытаясь говорить на иностранном языке. Если атмосфера в группе враждебная для студентов, они обеспокоены, что над ними смеются, речь становится невозможной. Многие проблемь могут появиться во время разговора и пользователи языка должны приспособить разговор к условиям. Знание определенных правил и принципов в абстрактном виде недостаточно. Для того чтобы отправить устное сообщение, докладчики должны быть в этом умелыми.

Преподаватели имеют решающее значение во взгляде обучения говорению, что студенть могут иметь. Преподаватели могут и должны сделать многое для того, чтобы проложить 
путь к большему количеству говорения на иностранном английском языке в классе. Чем больше будет устная практика, с которой сталкиваются студенты в классе, используя соответствуюшие методики, создавая благоприятную атмосферу, тем лучшими потребителями языка они постепенно станут. проблемьл.

Ключевые слова: преподавание языка, иностранный язык, студенты, обучение говорения, 